\title{
A BÜNÖZÖI ÉLETNARRATÍVA KONSTRUKCIÓI ÉS KAPCSOLATUK AZ ÉRZELMEKKEL
}

\author{
KOVÁCS ZSUZSANNA ${ }^{1}$ - BOROS JÁNOS ${ }^{2}$ - PATYI DÁNIEL ${ }^{3}$ - \\ SZUCSÁKI MELINDA ${ }^{4}$ \\ ${ }^{1}$ Veszprém Megyei Büntetés-végrehajtási Intézet \\ ${ }^{2}$ Pázmány Péter Katolikus Egyetem \\ ${ }^{3}$ Közép-dunántúli Országos Büntetés-végrehajtási Intézet \\ ${ }^{4}$ Büntetés-végrehajtás Országos Parancsnoksága \\ E-mail: pg.kovacs.zsuzsanna@gmail.com
}

Beérkezett: 2018. április 16. - Elfogadva: 2019. március 1.

Háttér és célkitûzések: Canter és Youngs (2009; Youngs és Canter, 2012) munkásságára támaszkodva a bünözók kriminális identitásának és emocionális élményének kapcsolatát kívántuk feltárni vizsgálatunkban.

Módszer: Youngs és Canter (2012) interjúmódszerét alkalmaztuk kutatásunk során, melynek eredményeként kimutattuk a magyar bünelkövetôk mintájában is azt a négy narratívatípust (Bosszúálló, Profi, Tragikus hös, Áldozat), amelyet a szerzók leirtak (vö. Boros, Kovács, Zs., Patyi, Szucsáki és Kovács, K., 2017). Kiegészítettük a típusok jellemzését a büncselekmény-narratíva, a kriminális elôtörténet és demográfiai adatok alapján. Megvizsgáltuk a négy narratívatípus érzelmi szervezödését. Az érzelmi kérdöív kvantitatív elemzését és a narratívumok tartalomelemzését végeztük el.

Eredmények: A büncselekmény közben átélt érzelmi élményról való utólagos beszámolóban az érzelmek a hatalom dimenziója mentén szervezödnek. A Profik esetében kevesebb negatív érzelem jelenik meg, mint a többi három típusnál. Az életnarratívum megkonstruálása az elvárt jellegzetességek szerint alakult, a Profik a redemptív, pozitívba hajló, a Bosszúállók a kontaminációs, negatívba hajló narratívaszervezôdést mutatták, míg az Áldozatok elhárító jelleggel a negatív eseményeket ignoráló, kizárólag a pozitív eseményekre fókuszáló történetszövést preferálták.

Következtetések: A bünelkövetók narratívaszervezôdésében jól azonosithatók az identitás-konstruálás érzelmi vetületei, amelyek segítségünkre lehetnek a társadalmi visszailleszkedési programok megtervezésében.

Kulcsszavak: büncselekmény-narratíva, tartalomelemzés, élettörténet, identitás, érzelmek 


\section{BEVEZETÉS}

Canter és Youngs (2012) megalkotta a bû́nözői narratívumok vizsgálatának elméleti keretét. Négy elmélet integrálására törekedtek munkásságukban. Az elsô elméleti pillér McAdams (2008) elmélete a narratív identitásról. Az énrôl alkotott narratíva az énkép fejlódésében és szervezésében játszik kiemelt szerepet. Az egyén a megtörtént eseményeket egyrészt elbeszéli, másrészt egyúttal értelmezi is, értelmes keretbe ágyazza, amely illeszkedik az önmagáról alkotott képéhez. Ez a folyamat biztosítja az egyén énérzetének idôbeli folytonosságát, és segít magyarázatot szolgáltatni az életesemények alakulására. Az elmélet szerint továbbá az egyén a világot két szociális érzelem, a hatalom és az intimitás mentén érzékeli, s ezek alapján kerül interakcióba vele.

A második elméleti pillér Presser (2009) elmélete a narratív kriminológiáról, amelynek központi gondolata, hogy a bünözók búncselekményükrôl mondott elbeszélései nem csupán utólagos értelmezései az eseményeknek, hanem szervezô erôként vesznek részt cselekvéseik irányításában.

A harmadik elméleti horgonypont a Frye (1957, idézi: Canter, Kaouri és Ioannou, 2003) által megalkotott „mítoszok elmélete”. Eszerint az ókortól a modern idôkig minden történet besorolható négy archetipikus narratívumtípus valamelyikébe. Ezek a típusok a következôk: komédia, románc, tragédia és irónia. Negyedik elméleti pillérként a Russell (1979, idézi: Canter és Ioannou, 2004) által azonosított érzelmek körére hivatkoznak. Eszerint az érzelmek két fô dimenzió mentén jellemezhetốk: a kellemesség-kellemetlenség dimenzió megadja az érzelem pozitív vagy negatív színezetét, a magas vagy alacsony arousal pedig leírja az érzelem által keltett aktivációs szintet.

Youngs és Canter (2012) négy bûnözôi típust határoztak meg a bûncselekmény során megélt érzelmek, identitás és kognitív torzítás alapján. A Profi bû́nözôi típusba tartozó elkövetố elbeszélésében kiemelkedik a kontroll, mindvégig uralja az eseményeket, a bûncselekmény elkövetését elvégzendố feladatnak, munkának tekinti, melyben kompetenciát és kellemes érzelmeket él át. Identitása erôs (magas hatalom), az áldozat személye irreleváns számára (alacsony intimitás). Az Áldozat típusának elbeszélésére a kontroll hiánya jellemzô, nincs befolyása a történések felett (alacsony hatalom), a számára fontos személyekhez (magas intimitás) ragaszkodik. Önmagát gyengének éli meg, másokat hibáztat a búncselekmény elkövetése miatt. A kontroll hiánya folytán nem érti a körülötte zajló eseményeket. A Tragikus hốs narratívájában is gyenge kontroll mutatkozik (alacsony hatalom), az elkövetố úgy érzi, a sors játékszereként olyan nehézségeket kell elviselnie, amelyeket nem érdemelt meg, tetteit nem uralja, másokra pedig nem képes hatást gyakorolni (alacsony intimitás). Az igazságtalanság elleni kétségbeesett küzdelmében nem képes felmérni a következményeket. A Bosszúálló narratívájában erôs identitással találkozunk, az elkövetô kontrollt érez környezete felett (magas hatalom), bûncselekményét számára jelentốs személyek jelenlétében (vagy sérelmére) követi el (magas intimitás), személyes elhivatottság vezérli tetteit.

Módszertani kidolgozottsága folytán kutatócsoportunk elsôsorban Youngs és Canter 2012-es tanulmányára hagyatkozik, a narratív kategóriák elnevezését is innen emeltük át, a vizsgálat lefolytatásának idején ez volt a szerzốk egyik legfrissebb publikációja. Más, késốbbi publikációikban azonban a narratív kategóriák eltérô elnevezésével találkozhatunk. A Bosszúálló típusra jellemző érzelmi színezetet és személyes énhatékonysá- 
got máshol a „Hero” (Canter és Youngs, 2012; Youngs és Canter, 2013) elnevezéssel illetik; a Tragikus hôs semleges érzelmi mintázata és környezete feletti gyenge kontrollja máshol a „Revenger” (Canter és Youngs, 2012) vagy „Distressed Revenger” (Ioannou, Canter és Youngs, 2017) elnevezést kapta. Mindezt azért tartjuk lényegesnek megemlíteni, hogy érzékeltessük, a narratív kategóriák elkülönítése az elméletalkotók számára is olykor nehézségekbe ütközött, illetve hangsúlyozzuk, hogy saját kutatásunkban az elsôként bemutatott besoroláshoz és elnevezésekhez ragaszkodtunk.

Az idevonatkozó szakirodalom alapján kijelenthetjük, hogy a kriminális narratíva mentén képzett négy típus meghatározott érzelmi mintázattal jellemezhetô: a Profik semleges vagy pozitív érzelmeket élnek át a bûncselekmény elkövetése közben, a Tragikus hôsök semleges érzelmeket, a Bosszúálók és az Áldozatok negatív érzelmeket (Youngs és Canter, 2012; Canter és Ioannou, 2004). Az érzelmek fontos tényezói nemcsak a búntett elkövetésének, hanem a búncselekmény megismétlésére irányuló szándéknak is (Ioannou, Canter és Youngs, 2017). Vizsgálatunkban a négy búnözői típus érzelmi kérdôíven mutatott különbségeit elemeztük.

Az érzelmi színezet további vizsgálatának alapját a mcadamsi (2008) módszertanból megismert kontamináció-redempció történetszervezési ellentétpár képezte, amely a negatív és pozitív érzelmi színezetú események sorrendje alapján kategorizál. Ha a vizsgálati személy a pozitív események után negatívval zárja a narratívát, akkor kontaminációs, ha a negatív eseményeket pozitív követi, akkor redempciós forgatókönyvrôl beszélünk. A redempció ebben az esetben azt jelenti, hogy a vizsgálati személy képes a negatív eseményeket pozitívvá konstruálni, amely nagyobb lelki egészséggel és pozitívabb énképpel jár. Búnözóknél ez nemcsak a jobb börtönadaptációt jelentheti, hanem megnövelheti a pszichológiai kezelések és reintegrációs beavatkozások hatékonyságának esélyét. A kontamináció ezzel ellentétes folyamat, itt az élettörténet fontos elemei negatív színezetet kapnak, ami rossz hangulatot, keserúséget, negatívabb énképet jelez, ez pedig rosszabb alkalmazkodást és rosszabb alapot jelenthet a rehabilitáció szempontjából.

A két narratíva elemzésével nemcsak típusaink leírása gazdagodik, hanem a fogvatartottak reintegratív kezeléséhez is fontos támpontokat nyerhetünk. A következókben bemutatjuk a narratívumok identitásteremtô és viselkedést irányító szerepét, valamint áttekintjük a bûnözők érzelmi szervezôdésére irányuló korábbi vizsgálatok eredményeit.

\section{Narrativa és érzelem}

Az érzelmek az ember mentális életének középpontját jelentik (Oatley és Jenkins, 2001). A búnözés magyarázatára született elméletek - biológiai, szociológiai, személyiséglélektani - sokáig kevés figyelmet szenteltek az érzelmeknek, mára azonban egyetértés alakult ki abban, hogy nem elhanyagolható az az érzelmi nyereség, amelyet a bûnözôk átélnek a bûntett elkövetése közben és utána, és amely hozzájárul azokhoz a hatásokhoz, amelyek fenntartják a kriminális aktivitást (Canter és Ioannou, 2004).

Katz (1988) azt a kérdést vizsgálta, hogy bûnözóknél az érzelmek teljes struktúrája kimutatható-e, valamint van-e kapcsolat a búncselekménytípusok között. Elkü- 
lönítette a búncselekmény elkövetése közben megélt érzelmi állapotokat. Erôszakos bûncselekményeknél a bosszú, megalázás, gúny, míg vagyon elleni bûncselekmények esetében leginkább a megszerzett tárgyak varázsa, valamint a bûncselekmény elkövetésében rejló izgalom volt azonosítható. Az érzelmek fontos szerepet játszanak a kriminális narratíva értelmezésében. Például az erôszakos bûnözók olyan érzelmeket élnek át a cselekmény elkövetése közben, mint a megalázás, becsületesség, arrogancia, nevetségesség, cinizmus, romlottság, bosszú. A vagyon elleni bûncselekmények fő érzelmi kíséróje a „titkos izgalom”, az elkövetôt maga a feladat, a búntett elkövetése vonzza. Ezek az elkövetôk sokszor nem rászorultságból követik el vagyon elleni cselekményeiket, tehát nem élelmiszert lopnak, hanem luxusholmikat, drogot vagy divatos ruhákat (Katz, 1988).

Russell 1979-es elméletére hivatkozva Canter és Ioannou (2004) két dimenzió mentén helyezte el az érzelmeket: kellemesség-kellemetlenség, valamint magas vagy alacsony arousal. A modell szerint az érzelmek a két fố tengely mentén körbe rendezôdnek. A kör közepét semleges pontként határozták meg; a hasonló érzelmek egymáshoz közel helyezkednek el. A két dimenzió keresztmetszetében négy érzelmi állapot különíthetô el: distressz (magas arousal, kellemetlenség), jókedv (magas arousal, kellemesség), nyugalom (alacsony arousal, kellemesség), depresszió (alacsony arousal, kellemetlenség).

Canter és Ioannou (2004) az elkövetôk által átélt érzelmek vizsgálata során eltérést azonosított a bûncselekménytípusok között. A legkellemesebb érzelmek a vagyon elleni büncselekményekhez társultak, a legkellemetlenebb érzelmek az erôszakos cselekményekhez kapcsolódtak (pl. szexuális bûncselekmények, rablás, testi sértés, emberölés), míg a kábítószerrel összefüggó búncselekmények elkövetôi a semleges állapothoz álltak közel.

Ioannou, Canter és Youngs (2017) szerint az egyes narratív szerepek jól azonosítható érzelmi mintázattal jellemezhetôk. Vizsgálatukban a kellemesség-kellemetlenség dimenzió mentén éles különbséget tapasztaltak az egyes narratív szerepek között, míg a magas-alacsony arousal mentén kevésbé differenciált eredményeket kaptak. Magyarázatuk szerint a bûncselekmények önmagukban megemelik az elkövetôk arousalszintjét, ezért nehezebben kimutatható ezen dimenzió differenciáló ereje a narratívatípusokban.

\section{Narratíva és viselkedés}

Canter (1994) szerint a kriminális aktivitás az ún. belsố narratívumokon keresztül érthetô meg, amely magába foglalja azokat a történeteket, amelyeket a bûnelkövetôk mondanak el arról, hogy miért ezt az életet választották. A belsố narratívumok tanulmányozása segít megérteni azokat a bûncselekményeket is, amelyekben nincs nyilvánvaló anyagi nyereség, vagy túl nagy a kockázat az elérhetố haszonhoz képest. Például egy fehérgalléros búnelkövetô hajlamos arra, hogy inkább vonakodó áldozatnak, mint manipulatív gazembernek tekintse önmagát. A búnbanda tagja kevésbé tekinti erôszakos akcióit egy agresszív verốember tetteinek, ezzel ellentétben úgy gondolkodik önmagáról, mint lendületes vezérról, vagy profi, „kemény fickóról”. Az az identitás, 
amit a bûnözôk kialakítanak magukról, kognitív folyamat eredménye, amely szociális kontextusban alakul ki, abban a kultúrában, amelyben a személy él. Ennek része a csoportgondolkodás általános mintázata és azoknak a személyeknek a véleménye, akikkel a búnelkövetô naponta érintkezik. Ezek az interakciók lehetôvé teszik számára, hogy tetteit legitimálja önmaga és a társai szemében, illetve semlegesítse akciói negatív következményeit.

A bûnözók narratív identitása átalakítja az élettörténetet, és ennek megfelelôen a bû́ncselekmény narratíváját is. Kérdés az, hogy ez a narratíva milyen hatással van a viselkedésre: csupán egy történet, amely felmentést ad az erkölcsi felelôsség alól, vagy pedig az életnarratívába ágyazódva viselkedési mintául szolgál, és elôsegíti a további bûncselekmények elkövetését? Presser (2009) és Toch (1993, idézi: Youngs és Canter, 2012) véleménye szerint a bûnözôi narratíva közvetlen elôzménye a bûntettnek, kulcsmotivációja az akciónak. A bûncselekmény narratívája a kognitív séma megvalósulása a gyakorlatban, nem csupán az elkövetett cselekmény interpretációja. Ezért figyelhetjük meg azt, hogy a szelf-narratívumok máshogy szervezôdnek visszaesôknél és máshogy azoknál, akik képesek felhagyni a bünözéssel (Ward és Maruna, 2007).

\section{Kognitív torzitás és énkép}

Az elítélés és bebörtönzés negatív hatást gyakorol a pszichés múködésre (szorongás, depresszió, alacsony önértékelés). Az eredményes adaptáció megkívánja ezek csökkentését és a börtönt megelôzố pozitív pszichés állapot visszaállítását (Boros és Csetneky, 2002). Már a korai kutatások foglalkoztak az úgynevezett „búnösségprobléma” megoldásával, amelynek során a leggyakrabban alkalmazott technika a bûnösség semlegesítése volt. Sykes és Matza (1957) öt formáját írták le ennek: a felelôsség tagadása, a kár tagadása, az áldozat tagadása, az „elutasítók” elutasítása, magasabb erkölcsi parancs szerinti cselekvés.

Ezek a technikák azt mutatják, hogy a bûnelkövetôk nem tagadják tettük elkövetését, de erkölcsileg nem tartják magukat felelôsnek, vagy legalábbis jelentősen csökkenteni tudják felelôsségüket és a pszichés distresszt is. Bandura $(1973,1990)$ az agresszív viselkedés kapcsán leírta az agresszív emberek önfelmentési technikáit. Ezek hasonlók a fent idézett semlegesítési módszerekhez: az agresszív tett utólagos átértékelése, magasabb elvekre való hivatkozás, a felelôsség áthárítása, a felelôsség megosztása, az áldozat dehumanizálása, az áldozat vádolása, a következmények félreértelmezése, deszenzitizáció az erôszakkal szemben.

Ezek a technikák egyrészt énvédô, racionalizáló funkcióval bírnak, segítenek viszszaállítani a pozitív énképet, másrészt a narratívába beépülve igazolják a viselkedés jogosságát, hozzájárulnak a kriminális identitás megerôsödéséhez, így ahhoz is, hogy az egyén megismételje a hasonló tetteket, fenntartsa búnözôi, illetve agresszív viselkedését. A kérdés az, hogy a különböző semlegesítési technikák hogyan épülnek be a kriminális narratívába, illetve hogyan segítenek annak specifikálásában.

A McAdams (2008) elméletében hangsúlyos szerepet kapó hatalom és intimitás szociális érzelmeiben a kognitív torzítások jól nyomon követhetôk. Kriminális kontextusban az intimitás kapcsán tényként fogadhatjuk el, hogy az alacsony intimitást 
mutató személyek minimalizálják a búntett hatását az áldozatra, míg a magas intimitásúak tisztában vannak az áldozatnak okozott negatív hatással, ezért inkább elkerülik azt, nem foglalkoznak vele, ehelyett saját céljaik megvalósítására fókuszálnak (Youngs és Canter, 2012).

Az alacsony hatalmú elkövetố nem a saját akciójával vagy saját céljai elérésével foglalkozik a történetben, hanem a felelôsséget a helyzetnek, illetve más személyeknek tulajdonítja. Vele szemben a magas hatalmú elkövető nemcsak irányítja az akciót, hanem saját maga értékeli, értelmezi át a tettet, és nem foglalkozik mások véleményével (Canter és Youngs, 2012). Láthatjuk, hogy az énképpel konzisztens kognitív torzítások tükrözik a kriminális identitást, és szervesen illeszkednek a kriminális narratívába.

\section{A bünözói narratíva további elemzési szempontjai}

A bevezetôben bemutatott narratívaelemzési módszert jelen kutatásban kiegészítettük az életnarratíva érzelmi dinamikájának elemzésével, amelynek gyakorlati jelentôségét McAdams és munkatársainak széles körú vizsgálatai igazolják (McAdams, Reynolds, Lewis, Pattern és Bowman, 2001; Dunlop, Guo és McAdams, 2016; Guo, Klevan és McAdams, 2016). Az élettörténetek konstruálása kétféle stratégiát követhet. Az elsôt redempciónak nevezzük, ez esetben az egyén az érzelmileg negatív, rossz életeseményt érzelmileg pozitívvá, jóvá alakítja át. A rossz élmény ezáltal enyhül, jóvátételre kerül, sốt az egyén hasznára válik. A másik stratégia a kontamináció, amelyben ezzel ellentétben az érzelmileg pozitív, jó élmény negatívaá, rosszá alakul át. A jót semmissé teszik, romba döntik a késôbbiekben bekövetkezô események (McAdams és mtsai, 2001).

Redempciós felépítés jellemzi az úgynevezett magasan generatív személyek (highly generative adults) életnarratívumait. A generativitás a középkorú felnôttek pszichoszociális adaptációjának mutatója, ezért a redempciót az elméletalkotók egyértelmúen az adaptációt meghatározó tényezôként azonosítják (McAdams és mtsai, 2001). A redempció jelenléte az élet fontos eseményeinek elbeszélésében pozitívan korrelált a pszichológiai jóllét önbeszámolós mutatóival. A kontamináció jelezte a depresszió szintjét, továbbá negatívan kapcsolódott az önértékeléshez és a koherenciaérzéshez (McAdams és mtsai, 2001).

McAdams (2008) narratív identitáselméletét, személyiségkoncepcióját és a fentiekben bemutatott redempció-kontamináció stratégiát az elsôk között Maruna integrálta a kriminálpszichológiai gyakorlatba (Maruna és Mann, 2006), fố kérdésfelvetése az volt, hogy mi különbözteti meg a búnözéssel felhagyó (dezisztens) és a bûnözést folytató elkövetôket. A dezisztencia az a fejlôdési folyamat, amelynek során az egyének önmagukat többé nem búnözôként határozzák meg, hanem alternatív identitást alakítanak ki. Az általa megalkotott Good Lives Model (GLM) központi gondolata, hogy a búnözók - a törvénytisztelố emberekhez hasonlóan - jó életet szeretnének élni; a különbség a két csoport között nem a motivációkban rejlik, hanem a nagyra értékelt célok elérésének eszközeiben (Maruna és Mann, 2006; Ward és Maruna, 2007).

A bûnözôk rehabilitációjának célja ennek alapján felvértezni az elkövetôket olyan képességekkel és értékekkel, amelyek által proszociális és jelentésteli életet élhetnek. Ez a folyamat a narratív identitás átalakításán keresztül valósul meg, mivel a hiányos 
vagy maladaptív narratív identitás újabb bûncselekmények elkövetésére predesztinálja a bûnözôket (Ward és Marshall, 2007).

Stone, Morash, Goodson, Smith és Cobbina (2016) feltételesen szabadlábra helyezett nôi elkövetôk narratív identitását és kriminális visszaesését vizsgálták. A 3 évet átfogó utánkövetéses vizsgálatban az újbóli letartóztatások száma mutatta a visszaesést. A regressziós modellben a redempció szignifikánsan jelezte a kevesebb számú új letartóztatást, míg a kontamináció szignifikánsan összefüggött az újabb letartóztatások magasabb számával.

Akik kontaminációt alkalmaztak az életnarratíva-interjúban, azokat nagyobb valószínúséggel tartóztatták le újra. Elbeszéléseikben nem szerepelt a búnözéstôl mentes jövôkép, önmagukra úgy tekintettek, mint akik visszafordíthatatlanul elromlottak, múltbéli hibáikkal azonosították magukat. Nem beszéltek arról, mit csinálhatnának másképp, hogyan juthatnának túl a múltbeli rossz élményeken, hogyan lehetne jobb a jövőjük. A redempciós forgatókönyvet alkalmazókra erôs személyes ágencia, proszociális és generatív jövôkép volt jellemzô. A múltbeli élmények alapján elmagyarázták, hogyan lettek erôsebbek, bölcsebbek, és hogyan képesek hatékonyabban kontrollálni a jövôjüket. Beszámoltak személyes fejlődésükrôl, iskolai vagy munkahelyi teljesítményükrôl (Stone és mtsai, 2016).

Farmer, Beech és Ward (2012) vizsgálatában 10 fố gyermekmolesztáló képezte a mintát, közülük öten abbahagyták a búncselekmények elkövetését, öten folytatták a törvényszegô viselkedést. A búnözéssel felhagyó elkövetôk mindegyike redempciót alkalmazott az életnarratívában, kiemelt hangsúlyú volt náluk a személyes ágencia szerepe, szégyenteljes múltjukat igyekeztek újraírni és produktív életet élni. A továbbra is aktívan bûnözó csoport esetében alacsony volt az ágencia, viselkedésüket külsô tényezôkkel magyarázták, a terápiának nem vették hasznát, elbeszéléseikben kontaminációt alkalmaztak, elidegenedettek voltak.

Életfogytiglani ítéletból szabadult elkövetôk (released lifers) vizsgálatában Liem és Richardson (2014) a narratíva átalakításának három kulcstényezőjét elemezték: a generatív motivációt, a központi ént (core self) és az ágenciaérzést. Dezisztensnek számított az, aki a szabadulást követô 5 év elteltével nem került vissza a börtönbe (a vizsgált 67 főbool 34-en). Szinte minden interjúban megjelent a központi én és a generatív motiváció, azokéban is, akik folytatták a bûnözést. Egyedül az egyéni ágencia volt az a kulcstényezô, amelyik megkülönböztette a társadalomba visszailleszkedô elkövetôket az újra börtönbe kerülôktốl. Az ágencia hiánya abban nyilvánult meg, hogy minimalizálták a saját szerepük megítélését azokban a körülményekben, amelyek visszavezettek a börtönbe. Életük irányításához passzív volt a hozzáállásuk, sikereiket és kudarcaikat külsố tényezôknek tulajdonították.

Összességében megállapítható, hogy az életnarratíva elemzése a kriminálpszichológiában lényeges szerepû. A narratíva mentén elkülönülő búnelkövetôi típusokba tartozó bûnelkövetôk nagy valószínûséggel eltérô forgatókönyveket alkalmaznak. A narratíva viselkedésük irányításában is szerepet játszik, ezért feltételezhetô, hogy az egyes típusokba tartozó elkövetôkre különbözố beilleszkedési mintázat jellemzố. Kutatócsoportunk az elsô, amely a kontamináció-redempció történetszervezést a négy búnözôi típusra nézve vizsgálta. 


\section{MÓDSZER}

\section{Cél és hipotézisek}

Jelen vizsgálat célja magyar bűnelkövetôk mintájában megvizsgálni a búncselekményhez kapcsolódó érzelmek, valamint a kontamináció és redempció alakulását Canter és Youngs (2009), illetve McAdams és munkatársai (2001) módszerei alapján.

Elsố hipotézisünk szerint a négy típus érzelmi mintázata a hatalom és identitás szerinti típusba sorolás kritériumainak megfelelô érzelmi szervezôdést mutat. A hipotézis vizsgálatához multidimenzionális skálázás módszert alkalmaztunk (Youngs és Canter, 2012).

Második hipotézisünk szerint a Profik inkább pozitív érzelmet élnek át a bû́ncselekmény elkövetése közben, a Bosszúállók és az Áldozatok inkább negatív érzelmeket, míg a Tragikus hôsök esetében semleges az érzelmi viszonyulás.

Harmadik hipotézisünk a következó: az általunk vizsgált narratívumokban a Profiknál nagyobb arányban jelenik meg a pozitívba forduló (redempciós) forgatókönyv, míg a Bosszúállók és Áldozatok esetében a negatívba forduló (kontaminációs) forgatókönyv.

\section{A vizsgálati eljárás bemutatása}

101 magyar bûnelkövetôvel (81 férfi, 20 nô) öt interjúvezetô vette fel a Canter-Youngs Narrative Experience interjút, amelyet a David Canter vezette kutatócsoporttal 2011-ben kötött együttmúködési megállapodás keretében bocsátottak rendelkezésünkre (Youngs és Canter, 2012). Az eljárás 60-90 percig tartott, négyszemközti helyzetben valósult meg, az interjúk rögzítése jegyzeteléssel történt. A résztvevôk beleegyezô nyilatkozatot töltöttek ki, és hozzájárultak adataik titkos és anonim módon történô kezeléséhez. A vizsgálatban való részvételért a fogvatartottak nem kaptak díjazást vagy egyéb jutalmazást. Három magyarországi börtön fogvatartottai képezték a mintát.

A minta életkori átlaga 33,2 év $(\mathrm{SD}=10,35)$, a legfiatalabb elkövetô 19 , a legidôsebb 67 éves. Az átlagos életkor az elsô rendôrségi ügynél 21,1 év, az elsô ítéletnél 24,4 év. Átlagosan 8,92 (SD = 2,69) iskolai osztályt végeztek el, egyéb képzésben $35 \%$ vett részt. Elsố bûncselekményük 54\%-a nem erôszakos bûntett. A résztvevôk 27\%-ának valamelyik szülôje büntetett elôéletû. Összesen átlagosan 5,3-szer $(\mathrm{SD}=4,81)$ ítélték el ôket, a legkevesebb ítélet 1 év, a legtöbb 28 év. Átlagosan 2,1 (SD = 1,26) különbözô kategóriájú bûncselekményt követtek el (például lopás, testi sértés, rablás, emberölés), a legkevesebb típus 1 , a legtöbb 6 . Az interjú során $44 \%$ számolt be nem erôszakos bûncselekményrôl, $56 \%$ erôszakosról.

Az interjúban három különbözó narratívát kértek a vizsgálatvezetôk. Az elsố a búncselekmény-narratíva. Az elkövetônek az általa tetszés szerint kiválasztott búncselekményrôl kellett beszámolnia. Az instrukció megegyezett az interjú megalkotói által alkalmazott kéréssel (az interjú kérdéseit David Canter egy együttmúködési szerzódés keretében bocsátotta kutatócsoportunk rendelkezésére, a módszer további bemuta- 
tását lásd: Youngs és Canter, 2012): „Arra kérem, meséljen egy búncselekményérôl, amit elkövetett, és amire tisztán vissza tud emlékezni. Olyat válasszon, ami olyan típusú búncselekmény, amilyet többet elkövetett korábban. Ha csak azt a búncselekményt követte el, amiért most börtönben van, arról meséljen. Kérem, az események minél több részletére térjen ki. Mondja el részletesen, mi történt. Mondja el, ki volt még benne. Mondja el, milyen hatással volt az Ön életére.” Segítô kérdések tisztázták a pontos körülményeket, a jelen lévô személyeket, az átélt érzelmeket, a kiváltó okokat és következményeket.

Ezután ki kellett választania az életéból egy lényeges eseményt, részletesen bemutatva, hogy miért volt fontos és milyen hatást gyakorolt az életére. Az instrukció így hangzott: „Szeretném, ha elmondana egy lényeges eseményt az életéból, amire tisztán emlékszik. Bármi lehet az. Mesélje el részletesen, hogy mi történt. Mondja el, miért volt ez fontos. Mondja el, milyen hatással volt ez az életére."

A harmadik kérdés során arról beszélt, hogy ha filmet forgatna a saját életérôl, az a film mirôl szólna, kik szerepelnének benne, mi lenne a film cselekménye. A saját életfilm átgondolása a lényeges eseményhez hasonlóan arra készteti a személyt, hogy tekintse át életét, és konstruáljon történetet az általa fontosnak tartott fordulópontok mentén. Az instrukció így hangzott: „Ha az életérôl filmet forgatnának, milyen típusú film lenne, és mi történne benne? Kik volnának a föszereplők? Mik lennének a fố események, amik történnek a filmben? Mit gondol, hogyan végződne a film?”

A bûncselekmény-narratívát három kódoló (mindhárman vizsgálatvezetôk is egyben) értékelte a hatalom és intimitás mentén, értékeléseik összevetése után többségi vagy konszenzusos döntés született a narratíva besorolásáról. Ez a kódolás tette lehetôvé a bûncselekmény narratívumkategóriájának azonosítását: magas hatalom és magas intimitás esetén Bosszúálló, magas hatalom és alacsony intimitás esetén Profi, alacsony hatalom és alacsony intimitás esetén Tragikus hôs, míg alacsony hatalom és magas intimitás esetén Áldozat típusba került a vizsgálati személy. (A kódoláshoz támpontot adó szempontokat az 1. táblázat mutatja be.) A minta 45,5\%-a a Profi narratív kategóriájába tartozott, Áldozat 24,8\%, Tragikus hôs 15,8\% és Bosszúálló 13,9\%.

A lényeges eseményt és a film narratívát a cselekmény dinamikája alapján kódolta három kódoló. Kontaminációs forgatókönyvrôl beszélünk, amennyiben a részletezett események egy kedvezô kiindulásból negatívba fordulnak, redempciós forgatókönyvrôl, ha a kezdeti negatív állapot pozitívá változik (McAdams és mtsai, 2001). További két lehetôség is felmerült: egyes esetekben a cselekmény mindvégig pozitív maradt, negatív elem nem szerepelt benne, illetve egyes forgatókönyvekben kizárólag negatív események szerepeltek, pozitív történések nélkül. Ezeket stabil pozitív és stabil negatív forgatókönyvekként azonosítottuk. A négy forgatókönyv-kategória kapcsán minden vizsgálati személy története kizárólag egy kategóriában kaphatott 1-es kódot, a többi háromban 0-t. Az egyes kódolók által adott értékeket összegeztük.

A három narratíva rögzítését követôen a fogvatartottak kitöltötték a búncselekmény során átélt érzelmekre vonatkozó, 26 itemes kérdôívet (Ioannou, Canter és Youngs, 2017). 1-tôl 5-ig terjedố skálán kellett jelölniük, hogy az interjúban említett bûncselekmény elkövetésekor milyen érzelmeket éltek át. Például: „férfias”, „bátor”, „összezavarodott”, „boldogtalan”. 
1. táblázat. A négy búnelkövetôi típus kogníció-, érzelem- és identitásmintázata

\begin{tabular}{l|l|l|l}
\hline & Kognitív torzítás & Érzelem & Identitás \\
\hline Tragikus hös & $\begin{array}{l}\text { Másra hárítja a büntett } \\
\text { felelősségét (AH). } \\
\text { Tettének következményeit } \\
\text { átértelmezi vagy } \\
\text { minimalizálja (AI). }\end{array}$ & $\begin{array}{l}\text { Magas arousal-szint (AH). } \\
\text { Semleges érzelmek (AI). }\end{array}$ & $\begin{array}{l}\text { Saját magát gyengének } \\
\text { értékeli (AH). } \\
\text { Mások (például az áldozat } \\
\text { személye) nem jelentősek } \\
\text { számára (AI). }\end{array}$ \\
\hline Áldozat & $\begin{array}{l}\text { Másokat okol a } \\
\text { cselekményért (MI). } \\
\text { Nem foglalkozik tettének } \\
\text { következményével (AH). }\end{array}$ & $\begin{array}{l}\text { Emelkedett arousal-szint } \\
\text { (AH). } \\
\text { Negatív érzelmek (MI). }\end{array}$ & $\begin{array}{l}\text { Saját magát gyengének } \\
\text { értékeli (AH). } \\
\text { Mások jelentösek számára } \\
\text { (MI). }\end{array}$ \\
\hline Profi & $\begin{array}{l}\text { Vállalja a felelösséget a } \\
\text { büncselekményért (MH). } \\
\text { Tettének következményeit } \\
\text { átértelmezi vagy } \\
\text { minimalizálja (AI). }\end{array}$ & $\begin{array}{l}\text { A büncselekmény } \\
\text { elkövetése közben nyugodt } \\
\text { (MH). } \\
\text { Semleges vagy pozitív } \\
\text { érzelmek (AI). }\end{array}$ & $\begin{array}{l}\text { Saját magát erósnek } \\
\text { értékeli (MH). } \\
\text { Mások nem jelentősek a } \\
\text { büntett kapcsán (AI). }\end{array}$ \\
\hline Bosszúlló & $\begin{array}{l}\text { Elismeri saját felelösségét } \\
\text { a büncselekményben } \\
\text { (MH). } \\
\text { Nem foglalkozik tettének } \\
\text { következményeivel (MI). }\end{array}$ & $\begin{array}{l}\text { A cselekmény elkövetése } \\
\text { közben nyugodt (MH). } \\
\text { Negatív érzelmek (MI). }\end{array}$ & $\begin{array}{l}\text { Saját magát erősnek } \\
\text { értékeli (MH). } \\
\text { Mások jelentősek a büntett } \\
\text { kialakulásában (MI). }\end{array}$ \\
\hline
\end{tabular}

Megjegyzés: A táblázatban alkalmazott rövidítések: $\mathrm{MH}=$ magas hatalom, $\mathrm{MI}=$ magas intimitás, $\mathrm{AH}=$ alacsony hatalom, $\mathrm{AI}=$ alacsony intimitás.

\section{A statisztikai elemzés bemutatása}

A statisztikai elemzésekhez SPSS 20. programot használtunk. Az elsô hipotézis vizsgálata multidimenzionális skálázás (eukleidészi távolságok) módszerrel valósult meg, melynek eredményeként kétdimenziós koordináta-rendszerben váltak ábrázolhatóvá a 26 tételes kérdôív tételei. Az így létrejött ábra értelmezését a kutatócsoport munkatársai végezték el.

A második hipotézis vizsgálatához elôször a 26 tételes érzelmi kérdôív tételeinek faktorelemzését végeztük el (fökomponens-elemzés varimax forgatással). 7 faktor emelkedett ki, amelyek sajátértéke 1-nél nagyobb, azonban a lejtôdiagram és az itemek tartalmának elemzése alapján végül a fix 4 faktoros megoldás megtartása mellett döntöttünk. Minden résztvevố esetében kiszámítottuk az egyes faktorokon elért pontszámokat. A négy narratív csoport közti pontszámbeli különbséget egyszempontos varianciaanalízissel vizsgáltuk Scheffé-próba utóteszttel.

A harmadik hipotézis vizsgálata szintén egyszempontos varianciaanalízissel valósult meg (Scheffé-próba utóteszttel), két külön elemzésben. Elôször a lényeges esemény narratívumokban, másodszor pedig a film narratívumokban azonosított négyféle forgatókönyv-megoszlásának különbségeit vizsgáltuk a négy búnözôi csoportban. 


\section{EREDMÉNYEK}

Az elsố hipotézis vizsgálatához az érzelmi kérdôív 26 tételének multidimenzionális skálázását végeztük el (1. ábra). Az ábra vízszintes tengelyén az érzelmek a hatalom dimenzió mentén rendezôdnek el. A vízszintes tengely bal oldalán a pozitív érzelmek helyezkednek el (magas hatalom), amelyek a Profikra és a Bosszúállókra jellemzók, a tengely jobb oldalán negatív érzelmeket találunk (alacsony hatalom), amelyeket az Áldozat és a Tragikus hốs típus tagjai élnek át a bûntett elkövetése közben.

A függóleges tengelyen a magas és alacsony intimitással jellemezhetố érzelmek nem rajzolódtak ki egyértelmúen. Várakozásunk szerint a magas és alacsony intimitáshoz tartozó érzelmek különbsége jobban elkülönül, hiszen a csoportba sorolásnál a magas és alacsony intimitás kritériumai voltak. A függôleges tengelyen az érzelmek az arousalszint alacsony vagy magas volta mentén sem különülnek el egyértelmúen, így sajnos meghiúsult az a tervünk, miszerint az ábra négy negyedében a négy narratív típusra jellemzô érzelmi mintázatot tudjuk megjeleníteni. Ismét hangsúlyozzuk, hogy az érzelmi élményt utólagos beszámoló alapján tártuk fel, azokat nem a bûncselekmény elkövetésekor rögzítettük.

Mindezek figyelembevételével elsố hipotézisünk, miszerint az érzelmi kérdôív tételei kirajzolják a hatalom és intimitás dimenzió tengelyén lévố négy típust, nem nyert igazolást.

A 26 érzelmet vizsgáló kérdôív faktorelemzése során feltárt négy faktor a variancia $55,85 \%$-át magyarázza $(\mathrm{KMO}=0,804)$. A négy faktor a következó: I. pozitív érzelmek (pl. magabiztos, elégedett, bátor, férfias, vidám, laza; Cronbach- $\alpha=0,864$ ), II. szoron-

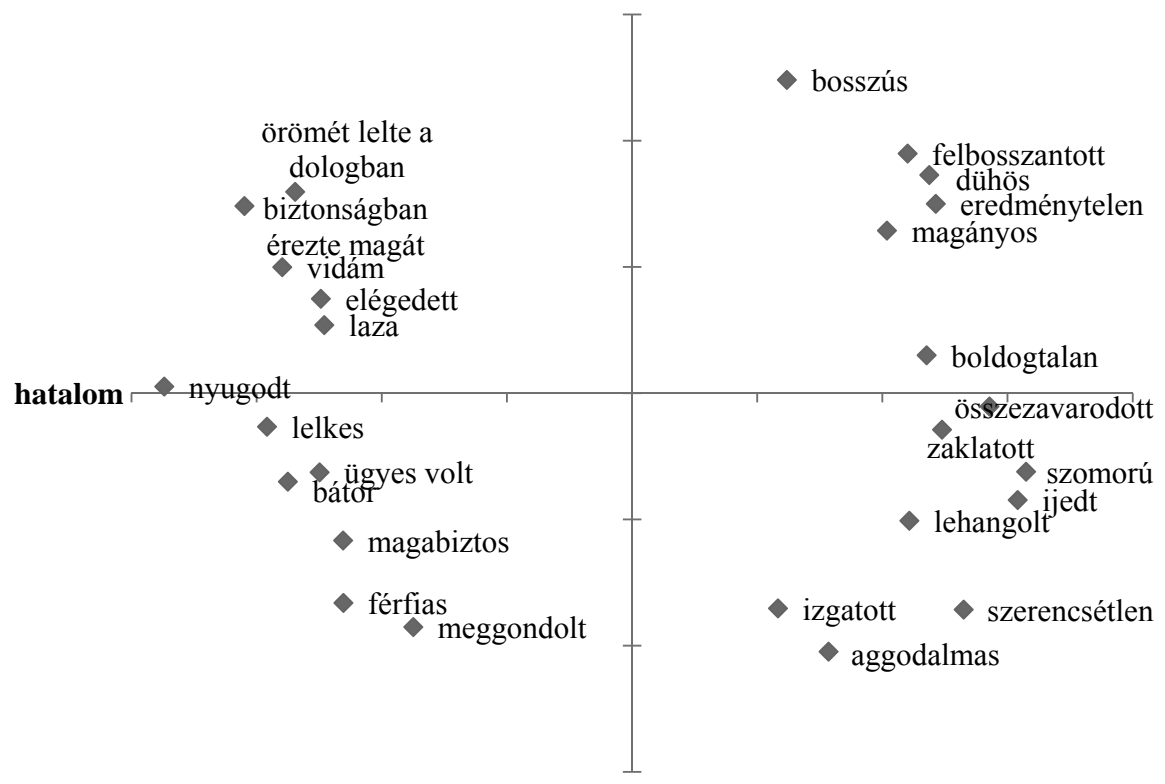

1. ábra. A 26 tételes érzelmi kérdôív MDS térképe 
gás (pl. zaklatott, izgatott, szomorú, ijedt; Cronbach- $\alpha=0,862$ ), III. düh (pl. bosszús, dühös, felbosszantott; Cronbach- $\alpha=0,857$ ), IV. elhagyatottság (pl. szerencsétlen, boldogtalan, aggodalmas, eredménytelen; Cronbach- $\alpha=0,702)$. Az elsố faktort pozitív érzelmek, míg a másik három faktort negatív érzelmek alkotják.

A második hipotézis vizsgálatához a varianciaanalízis eredményét a 2. táblázat mutatja be. A pozitív érzelmek faktorán (I. faktor) és a szorongással jellemezhetô érzelmekben (II. faktor) csupán tendenciaszintû a különbség a csoportok között ( $\mathrm{F}=2,271$, $\mathrm{p}=0,085$ és $\mathrm{F}=2,400, \mathrm{p}=0,073$ ). A dühös érzelmek (III. faktor) kapcsán szignifikáns a csoportok közötti különbség $(\mathrm{F}=7,762, \mathrm{p}<0,001)$, az utóelemzés feltárta, hogy a Profik lényegesen kevesebb dühös érzelmet élnek át a búncselekmény elkövetése közben, mint a Tragikus hôsök és a Bosszúállók. Az elhagyatottság érzelmei (IV. faktor) is jelentôs különbséget mutattak a csoportok között $(\mathrm{F}=4,578, \mathrm{p}=0,005)$. Az utóelemzés alapján elmondható, hogy a Profik lényegesen kevesebb elhagyatottságot éreznek, mint az Áldozatok.

A három negatív érzelmet jelzô faktor együttes elemzése szignifikáns eltérést mutatott a csoportok között $(\mathrm{F}=5,726, \mathrm{p}=0,001)$, az utóelemzés rámutatott, hogy a Profik kevesebb negatív érzelmet élnek át a bûncselekmény elkövetése közben, mint az Áldozatok és a Bosszúállók. A második hipotézis ugyan nem nyert alátámasztást, mindazonáltal elmondható, hogy a Profik kevesebb negatív érzelemmel szembesülnek bûncselekményük elkövetése közben, mint a másik három csoport tagjai.

A harmadik hipotézis vizsgálatához egyszempontos varianciaanalízist végeztünk a négy narratív kategóriában a négy típusú forgatókönyvre nézve, mind a lényeges esemény, mind a film narratíva kapcsán. Nem volt kritérium az egyetértés a kódolók között a forgatókönyv típusát illetően, hanem értékeléseiket összeadtuk. A lényeges esemény forgatókönyvtípusa kapcsán a három kódoló 43 esetben $(42,5 \%)$ egybehangzó értékelést adott, a film forgatókönyv-típusát illetően 58 esetben $(57,4 \%)$ voltak mindhárman azonos véleményen. Az értékelôk közti egyetértést jelző Cohen-féle kappaértékek 0,359 és 0,567 között alakultak, minden esetben elérték a 0,001\%-os szignifikanciaértéket, enyhe-közepes egyetértést jelezve.

A kódolók összesített ítélete alapján a lényeges életeseményben 27,39\% a kontaminációs forgatókönyv elôfordulása, 32,01\% a redempciós, vagyis negatívból pozitívba forduló forgatókönyv. 25,74\% a stabil pozitív és 14,85\% a stabil negatív hangulatú történet említési aránya (2. ábra).

2. táblázat. A 26 tételes érzelmi kérdôív faktorai, az ezeken elért pontszámok (zárójelben a szórásértékek), valamint az ANOVA eredménye

\begin{tabular}{|l|c|c|c|c|}
\hline & $\begin{array}{c}\text { I. faktor } \\
\text { Pozitív érzelmek }\end{array}$ & $\begin{array}{c}\text { II. faktor } \\
\text { Szorongás }\end{array}$ & $\begin{array}{c}\text { III. faktor } \\
\text { Düh }\end{array}$ & $\begin{array}{c}\text { IV. faktor } \\
\text { Elhagyatottság }\end{array}$ \\
\hline Profi & $26,69(9,60)$ & $22,40(8,32)$ & $5,63(3,51)$ & $8,91(3,76)$ \\
\hline Áldozat & $23,92(8,56)$ & $26,44(7,54)$ & $7,60(3,58)$ & $12,48(4,06)$ \\
\hline Tragikus hős & $26,13(11,77)$ & $26,81(12,75)$ & $9,50(4,35)$ & $11,56(5,04)$ \\
\hline Bosszúlló & $25,43(7,22)$ & $28,43(7,76)$ & $10,29(4,25)$ & $11,43(4,66)$ \\
\hline ANOVA eredménye & $\mathrm{F}=2,271$ & $\mathrm{~F}=2,400$ & $\mathrm{~F}=7,762$ & $\mathrm{~F}=4,578$ \\
& $\mathrm{p}=0,085$ & $\mathrm{p}=0,073$ & $\mathrm{p}<0,001$ & $\mathrm{p}=0,005$ \\
\hline
\end{tabular}




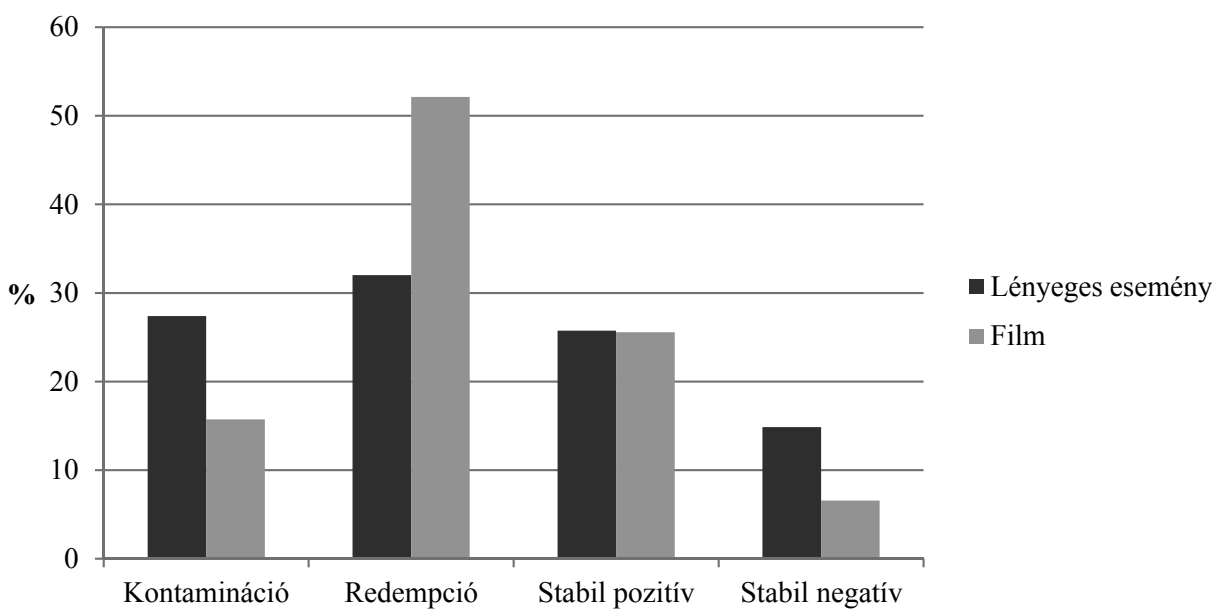

2. ábra. A lényeges esemény és film narratívumok forgatókönyvtípusainak százalékos megoszlása

Az egyes narratív kategóriákat tekintve a Bosszúállók kiemelkedtek a kontaminációs forgatókönyvek gyakoriságában, a Profik pedig a redempciós forgatókönyvek kapcsán (3. ábra). A varianciaanalízis és a Sheffé-próba utóteszt alapján elmondható, hogy a Bosszúállók lényeges eseményeiben szignifikánsan többször található kontaminációs forgatókönyv, mint az Áldozatokéban és a Profikéban $(\mathrm{F}=4,661, \mathrm{p}=0,004)$. Tendenciaszinten a Profik hajlamosabbak voltak a lényeges eseményben redempciós forgatókönyvet alkalmazni $(\mathrm{F}=2,572, \mathrm{p}=0,059)$. A lényeges esemény érzelmi dinami-

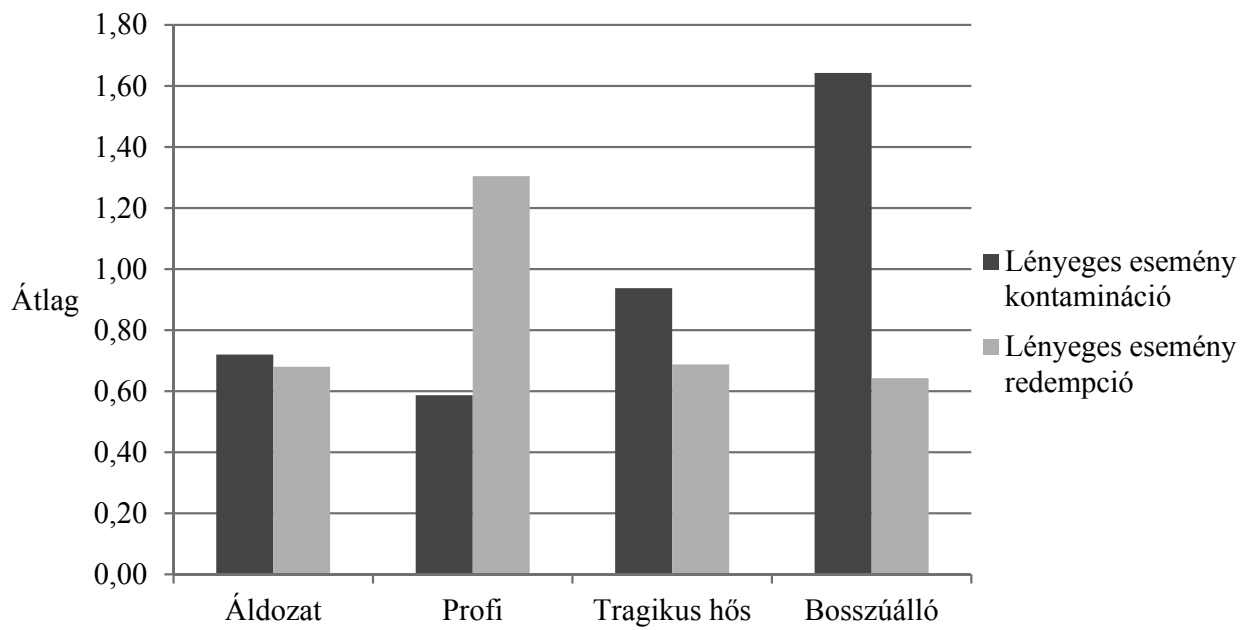

3. ábra. A kontaminációs és redempciós forgatókönyvú lényeges események előfordulása az egyes narratív kategóriákban 
kája az Áldozatok esetében szignifikánsan többször esett a stabil pozitív típusba, mint a Profik és a Bosszúállók esetében $(\mathrm{F}=3,297, \mathrm{p}=0,024)$.

A film narratívumok forgatókönyvtípusaiban - a lényeges eseménytốl eltérôen a redempciós forgatókönyv abszolút többségi arányban jelent meg (52,13\%), a második leggyakoribb a stabil pozitív $(25,57 \%)$ történet lett, a kontamináció aránya $15,74 \%$, a stabil negatív történet csupán 6,56\%-ban fordult elố. A statisztikai elemzés nem talált különbséget a négy búnözôi kategória között.

A vizsgálat harmadik hipotézise a lényeges eseménynarratívumok kapcsán igazolást nyert.

\section{MEGVITATÁS}

A búncselekmény elkövetésérôl elmondott narratívumban az érzelmek csupán a pozitív-negatív tengely, vagyis a hatalom dimenzió mentén különültek el élesen. Hasonló eredményre jutott Ioannou és mtsai (2017), hangsúlyozva, hogy a búncselekmény olyan magas arousalélményt kiváltó esemény, amely során a pozitív-negatív érzelmi dimenzió az utólagos beszámolóban jobban nyomon követhetố, mint az érzelmek más dimenzióban (például a magas-alacsony arousal dimenzióban) való elkülönülése.

Ennek oka feltehetốen a módszerben keresendô, a Canter-Youngs-féle érzelemlista nem, vagy csak kis mértékben tartalmaz olyan érzelmeket, amelyek lefednék az intimitás dimenzió teljes érzelmi spektrumát, így a vsz.-ek a bûntettrôl szóló beszámoló kontextusában képesek kifejezni az áldozathoz vagy a társaikhoz való kapcsolatuk intenzitását, az intimitást. Azonban amikor egy érzelemlistát kapnak, a feladat jóval bonyolultabbá válik, az érzelmi intelligencia gyengesége folytán elôtérbe kerül olyan érzelmek preferenciája is, amelyek a kriminális narratívában nem, inkább az életnarratívában fordulnak elô, és képezik fontos részét az énképnek. Eredményeink a négy narratív típust nem tudták tökéletesen elkülöníteni, csupán a magas hatalommal jellemezhetố Profik és Bosszúállók közös típusát, valamint az alacsony hatalommal jellemezhetố Tragikus hôsök és Áldozatok közös típusát.

A második hipotézis vizsgálata kapcsán fény derült arra, hogy a Profikra kevésbé jellemzô a negatív érzelmek átélése a büncselekmény elkövetése közben. Youngs és Canter (2012) eredeti feltételezésével szemben vizsgálatunkban a Bosszúállók érzelmi viszonyulása a negatív helyett inkább a semleges és pozitív érzelmek tartománya felé tolódott el.

A Profik esetében a pozitív érzelmek átélése logikusnak túnik, mivel a csoportba sorolás egyik kritériuma az érzelmek tekintetében az alacsony arousalszint mellett a semleges vagy pozitív érzelmek megjelenése volt a narratívában. Így a Profi nyugodtan, nagy szakértelemmel, biztonságos körülmények között szerzi meg az áhított javakat, pénzt, ékszert, elektronikai cikkeket, ami érthetôen elégedettséggel, örömmel tölti el. Kockáztat, de „befektetése” busásan megtérül, mert végül birtokolja a megszerzett értékeket. Canter és Ioannou (2004) eredményeivel egybevág, hogy a vagyon elleni elkövetôk örömet élnek át tettük elkövetése során.

Nem ilyen egyszerú a Bosszúállók helyzete, akiknél a csoportba sorolás kritériuma a negatív érzelmek megfogalmazása volt a kriminális narratíva megkonstruálásakor. 
Canter és Ioannou (2004) kutatásában distresszt éltek át az erôszakos cselekmények elkövetôi. Az önbeszámolós kérdôívben azonban magas hatalommal jellemezhetố érzelmeket deklaráltak, mint ügyes, bátor, férfias, magabiztos, meggondolt, amelyek inkább sikeres személyiségekre jellemzôk, mintsem búnözókre. Itt látszik, hogy a Bosszúállók pozitívabb énképe ezekből a momentumokból táplálkozik, amelyeknek kétségtelenül van alapjuk, hiszen gyôztek, bosszút álltak, erôsebbek, sikeresebbek voltak, mint áldozataik, de nem tudnak mit kezdeni a gyôztes párharc másik eredményével, a hosszú börtönbüntetéssel. Náluk hiányzik az a rugalmas kognitív készség, amelylyel a negatív eseményt semlegesíthetik és pozitívá alakíthatják (McAdams, 2008). Cselekményük, tulajdonságaik, érzelmeik túl pozitív értékelése nem teszi lehetôvé a valóság rugalmasabb átstrukturálását és a redemptív megoldások alkalmazását.

Az Âldozatok depresszív érzelmi mintázata megfelel a várakozásoknak. A Tragikus hôstôl semleges érzelmeket vártunk a kriminális narratívájuk alapján, az érzelmeket vizsgáló kérdôív azonban mást mutatott. A magányos és boldogtalan érzelmek mellett megjelent a bosszú, a felbosszantottság és a düh is, amely erôteljes, aktivitásra késztetô érzelmi töltést ad az elkövetett cselekménynek. A Tragikus hôsökre jellemzô magasabb arousalszint és a szituáció erôteljesen negatív pszichés élményt indukál, amely részben motiválja a sokszor hosszú idôn keresztül tartó búncselekmény elkövetését. A Tragikus hôsök tragédiáját nemcsak a sors, a végzet, a véletlen okozza, hanem az is, hogy az események közben bekövetkezô kisebb-nagyobb kudarcok, provokációk dühöt váltanak ki belôlük. Ez a düh párosul az alacsony kontrollal, elôidézve az események kedvezôtlen kimenetelét. A Tragikus hôsök az érzelmek mind a négy faktorán magas eredményt értek el (bár a többi csoporthoz képest nem minden esetben szignifikáns a különbség), ennek oka lehet egyrészt az, hogy alacsony az érzelmi intelligenciájuk, nehezen ismerik fel saját érzelmeiket, másrészt az átélt cselekmények változatossága az érzelmi élmény változatosságát is magával vonzza.

Az érzelmeket felsoroló kérdőív tételeinek multidimenzionális skálázása és faktorelemzése nem ugyanazt a képet mutatta a négy bûnözôi típust illetôen. Erre a jelenségre két magyarázat is lehetséges. Az egyik szerint a fogvatartottak kevésbé pontosan tudják azonosítani (fóleg utólag) az átélt érzelmeket (DeLisi, Umphress és Vaughn, 2009), ezáltal a kérdôíven adott pontszámok is differenciálatlan érzelmi világukat tükrözik. A másik lehetséges magyarázat szerint a búncselekmény elkövetése különféle események sorozatából tevôdik össze, amelyek eltérô, akár ellentétes érzelmi élményt is kiválthatnak az elkövetôben (Presser, 2016). A kérdőíven ezeket az érzelmeket felismerve bejelölhetnek akár egymásnak ellentmondó érzelmi állapotokat is.

Az életük egy lényeges eseményének elbeszélésében - a harmadik hipotézisnek megfelelóen - a Bosszúállókra volt a legjellemzóbb a kontaminációs forgatókönyv alkalmazása (vagyis a kezdeti pozitív állapotból egy fordulat hatására negatív állapotba való kerülés története). Tendenciaszinten mutatkozott meg a Profik ellentétes történetdinamikája, vagyis a redempciós (negatív kiinduló helyzetból pozitív fordulatot vevô) forgatókönyv előfordulása. Az Áldozat típus a Profikhoz és a Bosszúállókhoz képest többször alkalmazta a stabil pozitív történetmesélési dinamikát. Ez az eredmény a Profik esetében azzal magyarázható, hogy énerejük, kontrolljuk, önbizalmuk erôs; sikeres bûncselekmény-sorozatuk folytán életükkel kapcsolatban általában jellemzô rájuk a pozitív kimenetelben való reménykedés, emlékezetükben is könnyebben 
hozzáférhetốk az ilyen forgatókönyvet elôhívó történetek (Canter és Youngs, 2012). A Bosszúállók énerejüket nem tudják egyértelmúen az életükkel és jövôjjükkel kapcsolatos pozitív viszonyulás szolgálatába állítani. A sértetthez fúződô erôs érzelmi bevonódásuk által a cselekmény kapcsán kifogásokat, magyarázatokat keresnek. Az Áldozatok stabil pozitív történeteinek túlsúlya arról árulkodik, hogy mivel a búncselekmény során kiszolgáltatottnak érzik magukat, minden igyekezetükkel megpróbálják ezt ellensúlyozni, például úgy, hogy a búnözésben nem érintett szelf-részek kapcsán csak pozitív eseményeket idéznek fel a múltjukból.

A lényeges esemény eredményének elemzése kapcsán érdemes visszautalni a vizsgálati eredményeket bemutató korábbi tanulmányra (Boros mtsai, 2017). A Profik a bûnözố szubkultúrában sajátítják el nemcsak az elkövetés technikáját, de azt is, hogy miként zárják ki az „üzletből” az érzelmeiket. Megtanulják a többé-kevésbé tökéletes végrehajtást és a koncentrálást, amivel sikeresen fókuszálnak a végeredményre és ettốl nem tudja eltéríteni ôket senki és semmi. Emiatt kompetensnek érzik magukat, és az énképük pozitív lesz. Mindezekhez hozzájárul az a kognitív rugalmasság, amellyel életük negatív eseményeit pozitívvá tudják áttranszformálni, képesek élettörténetüket redemptív módon alakítani. Ezért náluk a reintegratív technikák alkalmazása inkább pozitív eredménnyel kecsegtet, mint a többi csoportnál. Gondolunk itt a Maruna-féle Good Lives modellre (Ward és Marshall, 2007).

A Bosszúállók szintén profi búnözők, akik azonban gyengébb érzelmi kontrollal rendelkeznek, sokszor az érzelmeik irányítják ôket, ami súlyosabb búncselekmények elkövetéséhez és lebukáshoz vezet. Cselekményüket igen pozitívan értékelik, azonban nem képesek redempciós megoldásokra életnarratívájuk megkonstruálása során, az általuk alkalmazott kontaminációs technikák sikertelenebb alkalmazkodást valószínúsítenek nemcsak börtönbüntetésük alatt, hanem szabadulásuk után is (Stone és mtsai, 2016).

Az Áldozat sikertelen bûnözô, folyamatos kudarcokkal. A film narratíva döntôen pozitív elemekbôl való felépítése nagy fokú elhárítást jelez, amellyel megpróbálja fenntartani énidentitását. Reintegrációra való esélye meglehetôsen alacsony (Ward és Maruna, 2007). A Tragikus hősnek nincs jellemző módszere az életnarratíva alakítására, nála a passzivitás, a kívülrốl irányítottság, kaotikus érzelmi élmény és a gyenge kontroll alakítja ki a búncselekmény sokszor bonyolult eseménysorozatát.

Mindezek az ismeretek hozzásegítenek bennünket ahhoz, hogy pontosabban tudjuk elkészíteni és személyre szabottan eltervezni a bûnelkövetốk rehabilitálására irányuló programokat. E kutatás alapján a szakemberek viszonylag kevés időbefektetéssel megismerhetik a fogvatartottak identitását, érzelmeit, kognitív torzításait és azt a kognitív képességét, amellyel életnarratívájukat megkonstruálják. Ezek az információk bármilyen elméleti alapú reintegrációs technika esetében használhatók, ám abban az esetben lehetnek a leghatékonyabbak, amikor a változás magára az életnarratívára irányul, amely életüket, viselkedésüket hosszú távon irányítja. Ezek közül a legkézenfekvốbb a már többször említett Good Lives modell (Ward és Marshall, 2007).

Példaként említhetjük a Profi narratív szerepet, amely vizsgálati mintánk 45\%-ára volt jellemzô. A Profik kompetens emberek, szakértôk, „szakmailag” kiválóak, önértékelésük pozitív, bứncselekményeik elkövetése során örömöt élnek át, nem foglalkoznak azzal, hogy a sértetteknek milyen kárt okoznak, életnarratíva-szerkesztésük 
redemptív típusú. Ez a típus jórészt pozitív tulajdonságokkal rendelkezik, amelyekre alapozni lehet az életnarratíva megváltoztatásakor a rehabilitáció folyamatában. A búnelkövetés közben átélt öröm arra készteti, hogy ismételje meg a cselekményt, hogy újra átélhesse a pozitív érzelmet. Az öröm sorozatos átélésére irányuló törekvés nem tekinthetô negatívnak, azonban az elkövetôk kompetenciáját és szakértelmét olyan aktivitási területre kell irányítani, amely társadalmilag elfogadott, emellett megfeleló jövedelmet biztosít. Ebben a folyamatban fontos szerepe lehet annak, hogy a Profit szenzitizáljuk az általa okozott kárra és a sértettnek okozott szenvedésekre. Miután a Profi életnarratívájában képes a negatív események átértelmezésére és a pozitív kicsengésú narratíva megkonstruálására, ezért az imént felvázolt lehetôség sikerrel kecsegtet az ilyen személyek társadalmi visszailleszkedésére, természetesen más, külsô tényezôk függvényében (Maruna, 2002).

A film narratívumok alapján szintén a kognitív szinten megvalósuló kompenzáció jelenségével találkozunk, mégpedig csoportok közötti különbség nélkül. A bûnelkövetốk nem tudják letagadni, hogy életük nem ideális íven haladt a múltban, az életükrôl forgatott filmben azonban a valóság helyett a fantáziájukra hagyatkozhatnak, amellyel megszépíthetik életük történetét. A redempciós forgatókönyvek többségi előfordulásának kedvezett az interjúban a történet végkifejletére irányuló kérdés is, amely által a válaszadók felszólítva érezhették magukat, hogy történetüknek valamilyen kedvezó befejezést találjanak ki.

Vizsgálatunk korlátját jelenti, hogy a narratívumok besorolása a kódolók értékelésén múlt, így magában hordozza az értékelésbeli különbségekból adódó módszertani gyengeséget. Mindennek ellenére ragaszkodtunk ahhoz, hogy minden vizsgálati személyt besoroljunk valamely narratívumkategóriába, mert fontos volt számunkra a teljes vizsgálati minta felhasználása a maga változatosságában. További korlátot jelent az éloobeszéd kézzel történô jegyzetelése, mivel a börtönben a hangrögzítésre ebben a vizsgálatban nem volt lehetôség.

Vizsgálatunkat eredményesnek tekintjük a bưnözôii életnarratíva és a bûnözô identitás dinamikájának feltárásában. A kutatás folytatásaként tervezzük az egyes búnözôi típusok énképének, adaptációjának, visszailleszkedési motivációjának további vizsgálatát.

\section{IRODALOM}

Bandura, A. (1973). Aggression. New Jersey: Prentice Hall.

Bandura, A. (1990). Mechanisms of moral disengagement. In Reich, A. (Ed.), Origins of terrorism, psychologies, ideologies, theologies, states of mind (pp. 161-191). New York: Cambridge University Press.

Boros, J., Kovács, Zs., Patyi, D., Szucsáki, M., \& Kovács, K. (2017). Búnözôi típusok azonosítása a bûncselekmény-narratívumokban. Magyar Pszichológiai Szemle, 72(3), 325-343.

Boros. J., \& Csetneky, L. (2002). Börtönpszichológia. Budapest: Rejtjel.

Canter, D. (1994). Criminal shadows. London: Harper-Collins.

Canter, D., Kaouri, C., \& Ioannou, M. (2003). The Facet Structure of Criminal Narratives. In Levy, S., \& Elizur, D. (Eds), Facet Theory: Towards a Cumulative Social Science (pp. 27-38). Ljubljana: Faculty of Arts, Center for Educational Development. 
Canter D. V., \& Ioannou, M. (2004). Criminals' Emotional Experiences During Crimes. International Journal of Forensic Psychology, 1(2), 71-81.

Canter, D., \& Youngs, D. (2009). Investigative Psychology: Offender Profiling and the Analysis of Criminal Action. Chichester: Wiley.

Canter, D., \& Youngs, D. (2012). Narratives of criminal action and forensic psychology. Legal and Criminological Psychology, 17, 262-275.

Cassese, E., \& Weber, C. (2011). Emotion, attribution and attitudes towards crime. Journal of Integrated Social Sciences, 2(1), 63-97.

DeLisi, M., Umphress, Z. R., \& Vaughn, M. G. (2009). The criminology of the amygdala. Criminal Justice and Behavior, 36(11), 1241-1252.

Dunlop, W. L., Guo, J., \& McAdams, D. P. (2016). The autobiographical author through time: Examining the degree of stability and change in redemptive and contaminated personal narratives. Social Psychological and Personality Science, 7(5), 428-436.

Farmer, M., Beech, A. R., \& Ward, T. (2012). Assessing desistance in child molesters: a qualitative analysis. Journal of Interpersonal Violence, 27(5), 930-950.

Guo, J., Klevan, M., \& McAdams, D. P. (2016). Personality traits, ego development, and the redemptive self. Personality and Social Psychology Bulletin, 42(11), 1551-1563.

Ioannou, M., Canter, D., \& Youngs, D. (2017). Criminal narrative experience: relating emotions to offence narrative roles during crime commission. International Journal of Offender Therapy and Comparative Criminology, 61(14), 1531-1553.

Katz, J. (1988). Seductions of Crime: Moral and Sensual Attractions in doing Evil. New York: Basic Books.

Liem, M., \& Richardson, N. J. (2014). The role of transformation narratives in desistance among released lifers. Criminal Justice and Behavior, 41(6), 692-712.

Maruna, S. (2002). Making good. How ex-convicts reform and rebuild their lives. Washington D.C.: American Psychological Association.

Maruna, S., \& Mann, R. E. (2006). A fundamental attribution error? Rethinking cognitive distortions. Legal and Criminal Psychology, 11(2), 155-177.

McAdams, D. P. (2008). Personal Narratives and the Life Story. In John, O. P., Robins, R. W., \& Pervin, L. A. (Eds), Handbook of Personality, Third Edition: Theory and Research (pp. 242-262). New York: The Guilford Press.

McAdams, D. P., Reynolds, J., Lewis, M., Pattern, A. H., \& Bowman, P. J. (2001). When bad things turn good and good things turn bad: Sequences of redemption and contamination in life narrative and their relation to psychosocial adaptation in midlife adults and in students. Personality and Social Psychology Bulletin, 27(4), 474-485.

Oatley, K., \& Jenkins, J. M. (2001). Érzelmeink. Budapest: Osiris Kiadó.

Presser, L. (2009). The narratives of offenders. Theoretical criminology, 13(2), 177-200.

Presser, L. (2016). Criminology and the narrative turn. Crime, Media, Culture, 12(2), 137-151.

Stone, R., Morash, M., Goodson, M., Smith, S., \& Cobbina, J. (2016). Women on parole, identity processes, and primary desistance. Feminist Criminology, first published online: September 26, 2016, Letöltve: 2017. 10. 23. https://doi.org/10.1177/1557085116670004

Sykes, G., \& Matza, D. (1957): Techniques of neutralization: A theory of delinquency. American Sociological Review, 22(6), 664-670.

Ward, T., \& Marshall, B. (2007). Narrative identity and offender rehabilitation. International Journal of Offender Therapy and Comparative Criminology, 51(3), 279-297.

Ward, T., \& Maruna, S. (2007). Rehabilitation. Beyond the risk paradigm. London and New York: Routledge, Taylor \& Francis Group. 
Youngs, D., \& Canter, D. (2009). An emerging research agenda for investigative interviewing: Hypotheses from the narrative action system. Journal of Investigative Psychology and Offender Profiling, 6(2), 91-99.

Youngs, D. E., \& Canter, D. V. (2012). Narrative roles in criminal action: An integrative framework for differentiating offenders. Legal and Criminological Psychology, 17(2), 233-249.

Youngs, D., \& Canter, D. (2013). Offenders' crime narratives as revealed by the narrative roles questionnaire. International Journal of Offender Therapy and Comparative Criminology, 57(3), 289-311.

\title{
CONSTRUCTIONS OF OFFENDER LIFE NARRATIVES AND THEIR RELATIONSHIP WITH EMOTIONS
}

\author{
KOVÁCS, ZSUZSANNA - BOROS, JÁNOS - PATYI, DÁNIEL - SZUCSÁKI, MELINDA
}

Background and aims: Based on Canter and Youngs' (Canter and Young, 2009; Youngs and Canter, 2012) work, our aim was to reveal the relationship between criminal identity and emotional experience of offenders.

Method: We used Youngs and Canter's (2012) interview method, we replicated their four narrative type (Revenger, Professional, Tragic hero, Victim) in a sample of Hungarian offenders (cf. Boros et al., 2017). We boradened the characterization of the types by data of criminal narratives, criminal history, and demographic characteristics. We studied the emotional pattern of the four narrative types. We performed a qualitative analysis of the emotional questionnaire and a conduct analysis of the narratives.

Results: When criminals report the emotional experience of their offence, emotions are organized on the dimension of potency. Professionals' emotional pattern is less negative than the other three types'. Construction of life narratives supported our hypothesis: Professionals showed a redemptive, Revengers showed a contaminated construction of narratives, and Victims preferred ignoring negative events and focusing only on positive events in their narratives.

Conclusion: We can clearly identify emotional characteristics of identity construction in criminals' narratives that can be helpful in planning reintegration programs.

Keywords: crime narrative, content analysis, life narrative, identity, emotions 
